\title{
Production of Chemotherapeutic agent L-asparaginase from Gamma-Irradiated Pseudomonas aeruginosa WCHPA075019.
}

\author{
Amany, B. Abd El-Aziz',*; Wesam, A. Hassanein²; Zakaria, A. Mattar; and Rabab, \\ A. El-Didamony ${ }^{2}$ \\ ${ }^{1}$ Microbiology Department, National Center for Radiation Research and Technology, Atomic Energy Authority, Nasr City, Cairo, \\ Egypt ${ }^{2}$ Department of Botany and Microbiology ‘ Faculty of Science, Zagazig University, Zagazig, Egypt.
}

Received: June 24, 2020; Revised: October 28, 2020; Accepted: November 10, 2020

\begin{abstract}
Because of the dangers and painful effects of chemotherapeutic drugs, the need for therapeutic agents with less adverse effects will increase several times in the coming years. L-asparaginase enzyme is an effective antitumor agent, especially acute lymphoblastic leukemia, with no side effects compared to other chemotherapeutic agents. Microorganisms are emerging as a safer source of L-asparaginase. Therefore, the findings of new L-asparaginase-producing bacterial strains with high yield for therapeutic applications become necessary. From twenty bacterial isolates tested for their L-asparaginase activity, 16S rRNA sequencing for the most potent isolate showed that the selected isolate had $100 \%$ identity to pseudomonas aeruginosa strain (accession number: WCHPA075019). In the presence of L-asparagine (1\%) and glucose (1\%) as nitrogen and carbon sources at a low dose of gamma radiation (0.75 kGy), the maximum productivity of Lasparaginase was reached after 2 days at $35^{\circ} \mathrm{C}, \mathrm{pH} 7.6$ under shaking at $200 \mathrm{rpm}$. Purification of L-asparaginase with $70 \%$ ammonium sulphate, followed by Sephadex G100 increases enzyme purity by 1.5-fold after gel filtration. Pure Lasparaginase had a molecular weight of $123 \mathrm{kDa}$ by SDS- PAGE. The maximum activity of the enzyme against L-asparagine was detected at $35^{\circ} \mathrm{C}$ and $\mathrm{pH} 9.0$ after $30 \mathrm{~min}$ and $200 \mathrm{mM}$ substrate. L-asparaginase activated in the presence of metal ions such as $\mathrm{K}+$, and $\mathrm{Na}^{+}$, not affected when exposed to EDTA and strongly inhibited in the presence of Ba2+, and Cd2+. The anticancer activity of the purified enzyme was tested in vitro against three types of cell line carcinoma. The growth inhibition of L-asparaginase for HEPG2 carcinoma cell line (IC50 value of $3.5 \mu \mathrm{g} / \mathrm{ml}$ ) was greater than the inhibition of HCT and MCF-7 carcinoma cell lines with IC50 value of 3.8 and $12.5 \mu \mathrm{g} / \mathrm{ml}$, respectively relative to the growth of the untreated control cells.
\end{abstract}

Keywords: pseudomonas aeruginosa, 16s rDNA analysis, L-asparaginase, Optimization, Gamma radiation, Purification, Enzyme activity, Anti-cancer.

\section{Introduction}

Microbial-source enzymes are potential biocatalysts used in various reactions and are part of the most essential products required to meet human needs in many fields (Olukunle and Ajayi, 2018). Approximately, 40\% of global enzyme sales are L-asparaginase, which considered as one of the major important biomedical and biotechnological groups of therapeutic enzymes (Qeshmi et al., 2018). L-asparagine is an essential amino acid used in normal and cancer cell nutritional requirements. The enzyme L-asparaginase converts L-asparagine to ammonia and aspartic acid (Chand et al., 2020). The major medical use of L-asparaginase is L-asparagine elimination from the blood of acute lymphoblastic leukemia (ALL) treated patients in order to prevent a recurrence (Gutierrez et al., 2006).

In the 19th WHO list of specific medicinal products, Lasparaginase enzyme is listed as a cytostatic adjuvant to acute lymphoblastic leukemia, as well as in the WHO model list of essential medicinal products for children (WHO, 2015).

The enzyme is commonly used as an anticancer agent because it is non-toxic biodegradable, cheap, and can be easily supplied at the local site. Recent clinical trials have shown that this enzyme is also a promising agent in the treatment of certain forms of human's neoplastic cells (Alrumman et al., 2019).

Because of immeasurably useful medical applications, L- asparaginase biotechnological production has become the subject of extensive research by many researchers worldwide. L-asparaginase activity was frequently reported in plants, micro-organisms (bacteria, fungi, and actinomycetes), animals, and in the serum of certain rodents but was not isolated from a human source (Lalitha and Ramanjaneyulu, 2016). Many genera of bacteria, Bacillus circuans (Prakasham et al., 2010), Bacilus brevis (Narta et al., 2011), Pseudomonas flurescens (Sinha et al., 2015), Pseudomonas aeruginosa (Saeed et al., 2018), and Escherichia coli (Kante et al., 2019) are reported as Lasparaginase producers.

\footnotetext{
* Corresponding author e-mail: abdelazizamany@gmail.com.
} 
Optimizing research conditions aiming to repeatedly increase L-asparaginase yield is the goal of many studies (Pallem, 2019). Among all the fermentation parameters tested, Prakasham et al. (2007) found that the inoculum volume incubation temperature and medium $\mathrm{pH}$ are the main effective parameters at a single level. These factors account for more than $60 \%$ of enzyme total yield. Furthermore, Arumugam and Senthil (2017) tested the effect of the nitrogen source on enzyme production under various conditions using the one factor at a time method (OFAT). Different studies indicated that low doses of gamma radiation can improve the growth and metabolism of microorganisms. Abdelrazek et al. (2019) use gamma rays to increase the productivity of L-asparaginase.

Specific purification steps were applied to the crude culture filtrate to obtain a pure enzymatic preparation. Various purifying steps, including ammonium sulfate fractionation, were followed by separation on Sephadex G100 and CM-Sephadex C50 (El-Bessoumy et al., 2004) or partial purification of the ammonium sulfate precipitation and dialysis (Arumugam and Senthil, 2017). Obtained results demonstrated an increase in treated L-asparaginase activity relative to the crude enzyme.

Some L-asparaginase preparations are currently approved for ALL treatment (Horvath et al., 2019). Asparaginase from Escherichia coli and E. chrysanthemi was considered for therapeutic purposes. Due to their serious side effects, such as liver dysfunction, allergies, and central nervous system disorders, it did not achieve complete remission, (Egler et al., 2016). To overcome these defects, further studies are required to find new bacterial strains that produce L-asparaginase without these effects (Fatima et al., 2019).

The aim of this research is to optimize the culture conditions for l-asparaginase production by a selected local bacterial isolate and to investigate the effect of various gamma irradiation low-doses on the production. Extraction and characterization of the purified enzyme and determination for the purified enzyme therapeutic efficacy as an anti-cancer in vitro against standard cancer cell lines were also evaluated.

\section{Materials and Methods}

\subsection{Materials}

\subsubsection{Chemicals and media.}

Analytical grade reagents and other chemicals were obtained from El-Gomhoria Company, Cairo, Egypt. From Sigma Aldrich (St. Louis, Missouri, USA), media and Lasparagine were bought.

\subsubsection{Samples}

Samples were collected from various asparagine rich sources and screened for isolation of bacteria-producing Lasparaginase. Bacterial samples have been isolated from fish, meat, cheese, rice, yellow lentils, asparagus, black lentils, potatoes, soybeans, eggs, milk, and beans. All sources were refined and exposed to the air for a day to activate bacterial growth.

\subsection{Methods}

2.2.1. Isolation, purification, and screening of bacterial isolates for $L$ - asparaginase production

For each sample taken, $10 \mathrm{~g}$ sample was inoculated in $90 \mathrm{ml}$ nutrient broth. The samples were serially diluted $\left(10^{-1}: 10^{-8}\right)$ and from each dilution, $0.1 \mathrm{ml}$ was streaked over solid modified M9 medium (Gulati et al., 1997). After $24 \mathrm{~h}$ of incubation at $37^{\circ} \mathrm{C}$, the pink color of the plate indicated L-asparaginase production. A single colony of each isolate was collected and streaked on nutrient agar medium several times until single pure colonies were obtained. Pure cultures were reserved at $4^{\circ} \mathrm{C}$ on slants of nutrient agar medium for further studies (Atlas and Parks, 1993).

2.2.2. Screening of bacterial isolates for $L$ - asparaginase production A. Qualitative assay of $L$-asparaginase

Screening procedure based on the principle that the $\mathrm{pH}$ indicator Phenol red was incorporated. It is yellow at $\mathrm{pH}$ below 7 (acidic $\mathrm{pH}$ ), and above $\mathrm{pH} 7$ it turns pink (alkaline $\mathrm{pH})$.

Primary screening using agar well diffusion (Magaldi et al., 2004).

Fifty $\mathrm{ml}$ of modified M9 broth medium was taken in conical flasks, inoculated with $1 \mathrm{ml}$ of $24 \mathrm{~h}$ aged bacterial culture suspension, and incubated for $24 \mathrm{~h}$ at $37^{\circ} \mathrm{C}$. After that, 30 min centrifugation for the culture broth was carried out at $4{ }^{\circ} \mathrm{C}$ and $5000 \mathrm{rpm}$. For each isolate, cellfree supernatant $(100 \mu \mathrm{l})$ was poured into a well $(8 \mathrm{~mm}$ diameter) in a modified M9 agar plate. At $4{ }^{\circ} \mathrm{C}$ for $12 \mathrm{~h}$, the inoculated plate was left to diffuse the filtrate into the medium and then incubated for $24 \mathrm{~h}$ at $37^{\circ} \mathrm{C}$. Diameters measuring of the pink area with a yellow background around the hole $(\mathrm{mm})$ stating L-asparaginase activity. The cultures with high enzyme production were selected for further studies.

Disc diffusion technique (Balouiri et al., 2016).

The isolated bacteria were inoculated in Erlenmeyer flasks of modified M9 broth medium and incubated for 24 h at $37{ }^{\circ} \mathrm{C}$. On sterilized filter paper discs $(6 \mathrm{~mm}) 25 \mu 1$ from cell-free supernatant was suspended. Then saturated discs were placed on the solid modified M9 medium surface and kept for $12 \mathrm{~h}$ at $4^{\circ} \mathrm{C}$ to allow diffusion of the filtrate and then the plates incubated for $24 \mathrm{~h}$ at $37^{\circ} \mathrm{C}$. Diameters of the pink zone around discs were measured, and the more L- asparaginase producer was selected for further studies.

B. Quantitative assay of $\mathbf{L}$-asparaginase (Imada et al., 1973).

The modified M9 medium ( $50 \mathrm{ml}$ ) has been inoculated with a 24-h old bacterial cell suspension $(2 \mathrm{ml})$, and the un-inoculated medium has been used as a control. The flask was incubated at $37^{\circ} \mathrm{C}$ with shaking (250 rpm) for 48 h. Centrifugation of the bacterial culture was carried out at $6000 \mathrm{rpm}$ for $20 \mathrm{~min}$.

\subsubsection{Estimation of L-asparaginase enzyme activity in culture filtrates}

Nesslerization determined the culture filtrate enzyme activity. From the cell-free supernatant or enzyme solution, $0.1 \mathrm{ml}$ of the sample was combined with $0.9 \mathrm{ml}$ $0.1 \mathrm{M}$ Tris- $\mathrm{HCl}$ buffer (pH 8.5), and then $1 \mathrm{ml} 0.04 \mathrm{M} \mathrm{L}-$ asparagine substrate was added. After incubating at $37^{\circ} \mathrm{C}$ 
for 30 minutes, the reaction was terminated with $0.5 \mathrm{ml}$ of tri-chloro-acetic acid (TCA) $1.5 \mathrm{M}$.

Dilution of $0.1 \mathrm{ml}$ of supernatant to $8 \mathrm{ml}$ using distilled water after centrifugation for protein precipitation occurred before treatment with Nessler's reagent $(1.0 \mathrm{ml})$. For 15 minutes, the brown reaction was allowed to proceed, and the ammonia release was estimated at $500 \mathrm{~nm}$. A typical ammonium-sulfate graph at different concentrations (1.5$11.8 \mu \mathrm{g} / \mathrm{ml}$ ) was used for evaluating the liberated ammonia.

\subsubsection{Determination of enzyme activity}

The released quantity of $\mathrm{NH}_{3}$ from asparagine is used to calculate the activity of the L-asparaginase enzyme (Peterson and Ciegler, 1969).

The International Unit (IU) identified the activity of the L-asparaginase enzyme as the quantity of enzyme needed to release one micromole of ammonia from L-asparagine per $\mathrm{ml}$ per minute $(\mu \mathrm{mole} / \mathrm{ml} / \mathrm{min})$ at $\mathrm{pH} 8.5$ and $37^{\circ} \mathrm{C}$ (Manna et al., 1995).

Bovine serum albumin (BSA) was used for the determination of protein contents (Lowery et al., 1951).

The amount of enzyme required for releasing $1 \mu$ mole of the product $/ \mathrm{min} / \mathrm{mg}$ of protein was considered as specific activity (Lalitha and Ramanjaneyulu, 2016).

\subsubsection{Characterization and identification of the most} potent $L$-asparaginase producing strain.

According to the standard biochemical and physiological identification test described in Bergey's Manual for Systematic Bacteriology, the most active isolate was identified (Brenner et al., 2005), and 16S rRNA gene sequencing was used for confirmation of the identification.

\section{Extraction of DNA}

On a rotary shaker (120 rpm), the selected bacterial strain was cultivated (on nutrient broth) overnight at $30^{\circ} \mathrm{C}$. Bacterial DNA has been extracted using the Bacterial Genomic DNA Mini-Prep Kit (Axygen cat. No. V11044005).

\section{Polymerase chain reaction (PCR)}

The specificity of primers is revised by the ribosome database (PROBE CHECK function) and BLAST search tool. In the Perkin Elmer 2400 (Nowalk, CT) thermo cycler, DNA amplification is performed on a pure $2 \mu \mathrm{l}$ to $3 \mu \mathrm{l}$ sample, each $1 \mu \mathrm{l}$ sample contains approximately 150 ng DNA. The final volume of PCR amplification reaction was $100 \mu \mathrm{l} ; 0.2 \mu \mathrm{M}$ from each primer (F1 and R1), $200 \mu \mathrm{M}$ dNTPs, $2.0 \mathrm{mM} \mathrm{MgCl} 2$ and 2.5 units of Maxima ${ }^{\circledR}$ Hot start Taq DNA polymerase (Fermentas, www. fermentas.com) mixed by PCR buffer (1X). The thermal cycle (PCR) steps were applied as follows; 5 min initial denaturation at $95^{\circ} \mathrm{C}$, followed by 35 cycles of denaturation at $94^{\circ} \mathrm{C}$ for $1 \mathrm{~min}$, primer annealing for $1 \mathrm{~min}$ at $55^{\circ} \mathrm{C}, 2 \mathrm{~min}$ extension at $72^{\circ} \mathrm{C}$. DNA was extended for $10 \mathrm{~min}$ at $72{ }^{\circ} \mathrm{C}$ after the last cycle (Khan et al., 2018).

\section{DNA Sequencing}

The amplification has been confirmed by analysis of 5 $\mu \mathrm{l}$ of the PCR product on $1 \%$ agarose gel (Promega) by electrophoresis. The size of the resulting PCR product ranged from 1450 to 1500 bp (Yamamoto and Harayama, 1998).
The PCR purification kit (Fermentas, Germany) was used for purification of the PCR products. Using the same PCR primers, the 16S rDNA amplicon was sequenced using an ABI377 DNA automatic sequencer (Perkin Elmer, Applied Bio-system Div., Waltham, USA).

\subsubsection{One variable at a time method for Optimization of L-asparaginase production}

Optimization of the experiments was carried out using a one factor at a time (OFAT) strategy. The effect of different nutritional and physiological parameters was evaluated by changing just one factor at a time and leaving the other factors stable. The physiological parameters that were investigated included initial $\mathrm{pH}$ (4.0-9.0), incubation time (18, 24, $48,60,72,84$, and $96 \mathrm{~h}$ ), and incubation temperature (from 25 to $60{ }^{\circ} \mathrm{C}$ ), with temperatures increasing by $5{ }^{\circ} \mathrm{C}$ each time. In order to test the impact of different sources of carbon and nitrogen (nutritional parameters), maltose, starch, fructose, lactose, xylose, sucrose, and mannitol ( $1 \% \mathrm{w} / \mathrm{v})$ were added separately to the M9 fermentation medium by replacing the glucose, and various sources of nitrogen (L-arginine, yeast, peptone, $\mathrm{NH}_{4} \mathrm{Cl}$, $\mathrm{NaNO}_{3}$, Glutamine, and $\mathrm{NH}_{4} \mathrm{SO}_{4}$ ) were added separately at final concentration equimolecular to locate in $5 \mathrm{~g}$ of $\mathrm{L}$ - asparagine. Under static and shaking conditions at various speeds of 100,150 , and $200 \mathrm{rpm}$, M9 basal liquid media were inoculated and incubated for $48 \mathrm{~h}$ at $35^{\circ} \mathrm{C}$ to study the effect of static and shaking conditions on the enzyme production.

\subsubsection{Influence of different gamma radiation doses on $L$ - asparaginase production}

At the National Center for Radiation Research and Technology in Nasr City, Cairo, Egypt, using an experimental ${ }^{60} \mathrm{Co}$ Russian gamma chamber, the M9 broth medium from the 24h test bacteria was exposed to various low doses of gamma radiation $(0.25,0.5,0.75$ and 1.5 $\mathrm{kGy}$ ). At the time of the experiment, the average dose rate was $1 \mathrm{kGy} / 50 \mathrm{~min}$. The irradiated samples were grown on flasks containing M9 medium at $\mathrm{pH} 7.6$ under shaking conditions at $200 \mathrm{rpm}$ and $35^{\circ} \mathrm{C}$ for $48 \mathrm{~h}$ (Abdelrazek et al., 2019).

The cell free filtrate was used at the end of each test period for measuring protein $(\mathrm{mg} / \mathrm{ml}$ ) and the activity of the enzyme $(\mathrm{U} / \mathrm{ml})$ as previously mentioned.

\subsubsection{Purification of L-Asparaginase Crude enzyme preparation}

The experimental strain was grown in the modified production medium (M9 medium) under optimal condition. The cell-free filtrate obtained after the culture fermentation was harvested, centrifuged (10,000 rpm) for 30 min and considered as the crude enzyme (Gulati et al., 1997).

\section{Ammonium sulphate precipitation}

A slow addition of ammonium sulphate to the crude enzyme by stirring was submitted at $4{ }^{\circ} \mathrm{C}$ until the desired saturation $(70 \%)$ of ammonium sulphate was achieved (Bollag et al., 1996). The mixture was kept at $4^{\circ} \mathrm{C}$ overnight, and then the protein precipitation was carried out by centrifugation $(10,000 \mathrm{rpm})$ for $15 \mathrm{~min}$ at $4^{\circ} \mathrm{C}$. The 
precipitate protein pellet was immediately dissolved at a minimal volume of $0.1 \mathrm{M}$ buffer (citrate phosphate: $\mathrm{pH} 7$ ). The protein content and enzyme activity of the dissolved fractional precipitate were tested.

\section{Dialysis}

Precipitated pellets were introduced into cellulose bag for dialysis against distilled water and then were dialyzed against phosphate buffer pH7.0 (Bhargavi and Jayamadhuri, 2016). The enzyme preparation was concentrated against polyethylene glycol crystals (PEG).

\section{Sephadex gel filtration}

The concentrated elution fractions were combined and applied to a Sephadex G-100 column $(2.5 \times 45 \mathrm{~cm})$ preequilibrated with the same buffer at a flow rate of $20 \mathrm{ml} / \mathrm{h}$. Combine the active fractions, concentrate, and examined for protein $(\mathrm{mg} / \mathrm{ml})$ content and enzyme activity $(\mathrm{U} / \mathrm{ml})$. The fraction with a sharp peak was pooled and concentrated by the dialysis membrane and used for further study (Bhargavi and Jayamadhuri, 2016).

\section{SDS- PAGE protein electrophoresis}

SDS-polyacrylamide gel electrophoresis (SDS-PAGE) was performed at the Regional Center for Mycology and Biotechnology Azhar University Cairo, Egypt. SDS-PAGE was made in accordance to the method of Laemmli (1970), using a $10 \%$ separating gel and 5\% stacking gel containing $0.1 \%$ SDS. The gel was strained with coomassie brilliant blue R-250. Then distained with methanol, acetic acid and water in the ratio of 4:1:5.

\section{Determination of molecular weight}

The molecular weight of the purified Lasparaginase was determined in comparison with standard molecular weight markers phosphorylase b (97.4 kDa), Bovine serum albumin (66.2kDa), Ovalbumin (45 kDa), carbonic anhydrase (25 kDa) and lactoglobulin (18.4 kDa). Standard curve for protein marker was drawn based on the electrophoretic mobility (Rf) of proteins against their $\log 10$ molecular weights.

\subsubsection{Biochemical Properties of the purified $L$ -} asparaginase enzyme

Effect of pH: The purified enzyme and asparagine reaction mixture were adjusted to different $\mathrm{pH}$ values (4.09.0) at $35^{\circ} \mathrm{C}$ for $30 \mathrm{~min}$.

Effect of different incubation temperature: The purified enzyme and asparagine reaction mixture has been incubated for $30 \mathrm{~min}$ at various temperatures $(25,30,35$, 40, 45, 50, 55 and $60^{\circ} \mathrm{C}$ ).

Effect of reaction time: The reaction mixture incubated for $5,10,15,20,25,30,35,40,45,50,55$, and $60 \mathrm{~min}$.

Effect of substrate different concentrations (Lasparagine): Different concentrations of L-asparagine (50, 100, 150, 200, 250 and $300 \mathrm{mM}$ ) were used.
Effect of Metal ions (activator / inhibitor): Purified enzymes were separately pre-incubated with different metal ions $\left(\mathrm{Cu}^{+2}, \mathrm{Fe}^{+2}, \mathrm{Zn}^{+2}, \mathrm{EDTA}^{+2}, \mathrm{Co}^{+2}, \mathrm{Ba}^{+2}, \mathrm{Ca}^{+2}\right.$, $\mathrm{Mn}^{+2}, \mathrm{Mg}^{+2}, \mathrm{~K}^{+}, \mathrm{Na}^{+} \& \mathrm{Cd}^{+2}$ ) for 30 minutes prior to the addition of asparagine $(40 \mathrm{mM})$. At the end of the incubation period, the enzyme activity was measured by using the cell-free filtrate, as previously mentioned.

\subsubsection{Anticancer activity}

Cell Viability Assay for three cell lines: human hepatocarcinoma hepG2 cell line, colon cancer HCT, and human breast adenocarcinoma (MCF-7), which were from the American Model Culture Collection (ATC Collection, Minisota, United States) have been performed by the Cairo National Cancer Institute in Egypt using MTT (3-(4, 5dimethyl-2)-2, 5-diphenyltetrazolym bromide. The viability of MTT cells was determined according to Vichai and Kirtikara (2006).

Percentage of cell viability $=$ Optical Density for the treated cells / control cells Optical Density * 100 .

Sigmoidal dose-response curve-fitting models (Graphpad Prizm Software, version 3) were used to detect L- asparaginase as an anticancer against three human cell lines.

\subsubsection{Statistics and calculations}

For each analysis, results have been expressed as a mean \pm SD (standard deviation). All tests have been conducted in triplicates, $\mathrm{n}=3$.

\section{Results and Discussion}

\subsection{Screening of isolated bacteria for production of $L$ - asparaginase.}

Twenty bacterial isolates were randomly isolated from fish, meat, cheese, rice, yellow lentils, asparagus, black lentils, potatoes, soybeans, eggs, milk, and beans. The data showed that the majority of the isolates are gram-positive, rod-shaped and spore-forming. Modified M9 with a sole source of nitrogen (asparagine, 1\%) was the medium used for screening the activity of all isolated bacteria for Lasparaginase production. The change of yellow color of media to pink is a positive indicator for the enzyme production. The plate culture assay indicated that all bacterial isolates exhibited positive production for Lasparaginase with different zone diameter, which provides an assay for L-asparaginase activity. L-asparaginase efficacy was tested spectrophotometrically. Table 1 results show the activity of L-asparaginase in $\mathrm{U} / \mathrm{ml}$, and the pink zone $(\mathrm{mm})$ diameter. L-asparaginase activity of the isolates was observed to range from 12.0 to $44 \mathrm{U} / \mathrm{ml}$ and the diameter to range from 12 to $37 \mathrm{~mm}$ using both agar-well and disk diffusion methods. It is in agreement with Gulati et al. (1997), who proved that the transformation of medium color to pinkish was triggered by the production of L-asparaginase. 
Table 1. Screening of isolated bacteria for production of Lasparaginase

\begin{tabular}{|c|c|c|c|c|c|}
\hline $\begin{array}{l}\text { Isolate } \\
\text { no }\end{array}$ & $\begin{array}{l}\text { Sample } \\
\text { source }\end{array}$ & $\begin{array}{l}\text { Agar well } \\
\text { diffusion } \\
\text { (mm) Pink } \\
\text { zone } \\
\text { diameter }\end{array}$ & $\begin{array}{l}\text { Protein } \\
(\mathrm{mg} / \mathrm{ml})\end{array}$ & $\begin{array}{l}\text { Activity } \\
(\mathrm{U} / \mathrm{ml})\end{array}$ & $\begin{array}{l}\text { Specific } \\
\text { activity } \\
\text { (U/mg) }\end{array}$ \\
\hline 1 & Fish & 17 & 0.160 & 15.0 & 93.16 \\
\hline 2 & Fish & 16 & 0.173 & 18.0 & 104.0 \\
\hline 3 & Fish & 15 & 0.158 & 15.0 & 94.90 \\
\hline 4 & Meat & 13 & 0.251 & 14.7 & 58.48 \\
\hline 5 & Cheese & 12 & 0.160 & 12.0 & 75.00 \\
\hline 6 & Rice & 18 & 0.190 & 10.5 & 55.63 \\
\hline 7 & Yellow lentil & 29 & 0.240 & 32.6 & 135.0 \\
\hline$* 8$ & Asparagus & 36 & 0.320 & 44.0 & 137.7 \\
\hline 9 & Black lentil & 28 & 0.280 & 34.4 & 122.8 \\
\hline 10 & Black lentil & 26 & 0.252 & 31.8 & 126.3 \\
\hline 11 & Potato & 18 & 0.280 & 15.53 & 55.40 \\
\hline 12 & Potato & 19 & 0.220 & 14.5 & 65.90 \\
\hline 13 & Potato & 19 & 0.250 & 16.6 & 66.40 \\
\hline 14 & Soybeans & 30 & 0.260 & 32.0 & 123.0 \\
\hline 15 & Soybeans & 28 & 0.270 & 30.0 & 111.1 \\
\hline 16 & Egg & 18 & 0.216 & 21.21 & 69.09 \\
\hline 17 & Milk & 23 & 0.200 & 27.20 & 105.7 \\
\hline 18 & Milk & 20 & 0.231 & 26.0 & 112.1 \\
\hline 19 & Beans & 22 & 0.190 & 30.0 & 120.8 \\
\hline 20 & Beans & 21 & 0.232 & 29.2 & 125.3 \\
\hline
\end{tabular}

*Out of twenty isolates, isolate no 8 was selected as the most Lasparaginase producer.

\subsection{Identification and characterization of the most potent isolate}

The isolate number (8) was identified using the tests of systematic bacteriology guided by Bergey`s Manual, and the results indicated that it belonged to the genus pseudomonas (Paul and Sinha, 2014). For confirming the identification, isolate No 8 DNA was extracted directly from the organism. Based on the alignment of 16s rDNA available in the gene bank, two primer set was used. $1 \mathrm{~kb}$ DNA product was obtained in confirmation genus identification. On the other hand, BLAST searches were performed to investigate whether high homology of tested strain exits to other Pseudomonas. The genomic DNA for the bacterial isolates was used as a template for the amplification of rRNA using the forward and reverse primers for 16S rDNA (Figure 1). After running of PCR and agarose gel (Figure 2), the purified PCR products from $P$. aeruginosa were sequenced and the sequence obtained was deposited with the accession number WCHPA075019 in the bank of gene (Figure 3). BLAST studies have shown that the strain tested has a $100 \%$ identity with pseudomonas aeruginosa and it was identified as pseudomonas aeruginosa WCHPA075019.
R:

GGTGCCGGTGCTTATTCTGTTGGTAACGTCAAAACAGCAGGTATTAACTTACTGCCCTTC CTCCCAACTTAAAGTGCTITACAATCCGAAGACCTTCTTCACACACGCGGCATGGCTGGA TCAGGCTTTCGCCCATTGTCCAATATTCCCCACTGCTGCCTCCCGTAGGAGTCTGGACCG TGTCTCAGTTCCAGTGTGACTGATCATCCTCTCAGACCAGTTACGGATCGTCGCCTTGGT AGGCCTITACCCCACCAACTAGCTAATCCGACCTAGGCTCATCTGATAGCGTGAGGTCC GAAGATCCCCCACTITCTCCCTCAGGACGTATGCGGTATTAGCGCCCGTTTCCGGACGTT ATCCCCCACTACCAGGCAGATTCCTAGGCATTACTCACCCGTCCGCCGCTGAATCCAGGA GCAAGCTCCCTTCATCCGCTCGACTTGCATGTGTTAGGCCTGCCGCCAGCGTTCAATCTG AGCCAGGATCAACTTCTCCAA

\section{F:}

AAACCGCTGGCGGCAGGCCTAAACATGCAAGTCGAGCGGATGAAGGGAGCTTGCTCCT GGATTCAGCGGCGGACGGGTGAGTAATGCCTAGGAATCTGCCTGGTAGTGGGGGATA ACGTCCGGAAACGGGCGCTAATACCGCATACGTCCTGAGGGAGAAAGTGGGGGATCT CGGACCTCACGCTATCAGATGAGCCTAGGTCGGATTAGCTAGTTGGTGGGGTAAAGGC CTACCAAGGCGACGATCCGTAACTGGTCTGAGAGGATGATCAGTCACACTGGAACTGA GACACGGTCCAGACTCCTACGGGAGGCAGCAGTGGGGAATATTGGACAATGGGCGAA AGCCTGATCCAGCCATGCCGCGTGTGTGAAGAAGGTCTTCGGATTGTAAAGCACTTTAA GTTGGGAGGAAGGGCAGTAAGTTAATACCTTGCTGITTTGACGTTACCAACAGAATAAG CACCGGCTAACTTCGTGCCAGCAGCCGGGTAATAATACAGCGCTAAACCCACAGCGGG GCTTITAATTTGAAGGCTTTCCTITITGCCGAATCGCTGGGTCAGGCTCATGCCAGTTC CAATATCCATATTTCCCACTCCCGATGGAGTTCGGACCTGGTC

Figure 1. DNA sequences of pseudomonas aeruginosa.

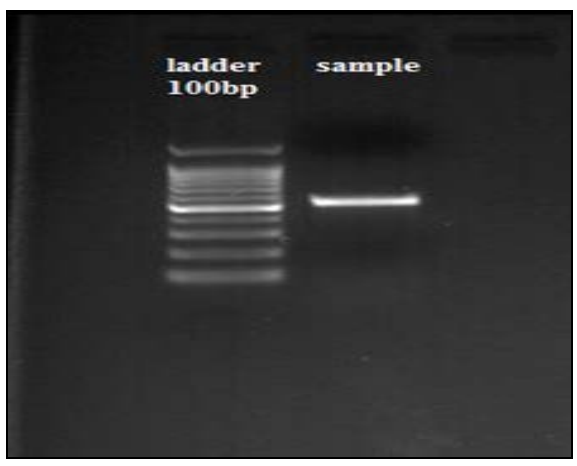

Figure 2. PCR product of $16 \mathrm{~S}$ rRNA of pseudomonas aeruginosa.

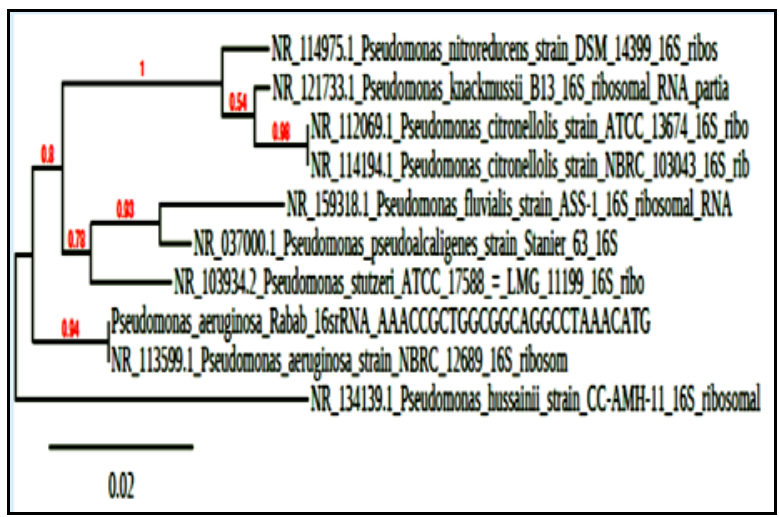

Figure 3. Phylogenetic tree analysis of pseudomonas aeruginosa WCHPA075019 obtained after performing 16S rRNA sequencing

This is in accordance with Badoei-Dalfard (2015) and Jois et al. (2013) who reported that $P$. aeruginosa is a good L-asparaginase producer.

\subsection{Optimization of P. aeruginosa WCHPA075019 L- asparaginase production}

To optimize Pseudomonas aeruginosa L-asparaginase production, many cultural and nutritional parameters were examined. The maximum enzyme production was exhibited at $35^{\circ} \mathrm{C}$ for 2 days and $\mathrm{pH} 7.6$ in presence of $1 \%$ glucose and L-asparagine under shaking condition at 200 rpm (Figure 4). Such findings are in accordance with Komathi et al. (2013) who stated that the maximum 
enzyme production by $P$. aeruginosa was after $48 \mathrm{~h}$ of incubation at $35^{\circ} \mathrm{C}$ and $\mathrm{pH}$ 7.6.

Badoei-Dalfard (2016) revealed that with Lasparaginase and glucose as nitrogen and carbon sources, the largest amount of L-asparaginase by $P$. pseudoalcaligens JHS-71 was obtained at $\mathrm{pH} 7.0$ and $37^{\circ} \mathrm{C}$ after $48 \mathrm{~h}$. This result was consistent with the data recorded by Badoei-Dalfard (2015), which showed that $P$. aeruginosa strain SN004 maximum production was achieved when glucose was used as carbon source. Various sources of organic and inorganic nitrogen have been tested. The present data showed that $P$. aeruginosa WCHPA075019 was capable of using both organic and inorganic nitrogen sources. L-asparagine was the ideal nitrogen source for the L-asparaginase production (170.7 Umg-1), which indicates that L-asparagine is an Lasparaginase inducer. This results in accordance with Badoei-Dalfard (2015), who confirmed that $(0.5 \%)$ Lasparagine is the best source of nitrogen for $P$. aeruginosa strain SN004 L-asparaginase maximum production (785 U / ml). Shukla and Mandal (2013) reported that the use of L-asparagine followed by peptone and yeast extract can achieve Bacillus subtilis L-asparaginase maximum yield. The maximum enzyme production by $P$. aeruginosa WCHPA075019 occurred at $200 \mathrm{rpm}$. Also, Kuwabara et al. (2015) reported that at $200 \mathrm{rpm} P$. aeruginosa PAO1 Lasparaginase maximum production took place.
3.4. Influence of different gamma radiation doses on $L$ asparaginase production

Numerous studies have shown that low gamma irradiation doses can improve metabolic activities and microbial development. $P$. aeruginosa was exposed to gamma rays at doses from 0.25 to $1.5 \mathrm{kGy}$ using an experimental ${ }^{60}$ Co Russian gamma chamber, (dose rate $1 \mathrm{kGy} / 50 \mathrm{~min})$. Results showed that enzyme activity increased gradually from 0.25 to $0.75 \mathrm{kGy}$ and maximum activity at $0.75 \mathrm{kGy}$ and decreased sharply at $1.0 \mathrm{kGy}$ dose and had no activity at $1.5 \mathrm{kGy}$ (Figure 5). This result is in agreement with Abd EI-Aziz and Hassan (2010) who showed that radiation dose level 0.75kGy resulted in an increase in the elastase yield of Bacillus subtilis by $7.94 \%$ and in the final dry weight when compared with nonirradiated control. The inhibitory effect of radiation on a microbial enzyme may be due to the action of ionizing radiation on either of the two components of which the enzymes are made up, i.e. the protein or the prosthetic group. When acting on protein moiety they may oxidize reactive groups, amino groups or double bonds or may act by or precipitation, when acting on the prosthetic group they may produce chemical changes that alter the biological activity of the enzyme (Reisz et al., 2014). On the other hand, the improvement by gamma radiation may either be due to an increase in gene copy or gene expression or both (Rajoka et al., 1998) and by inducing mutagenesis in the microbial cell to enhance its activity for enzyme production (Awan et al., 2011).

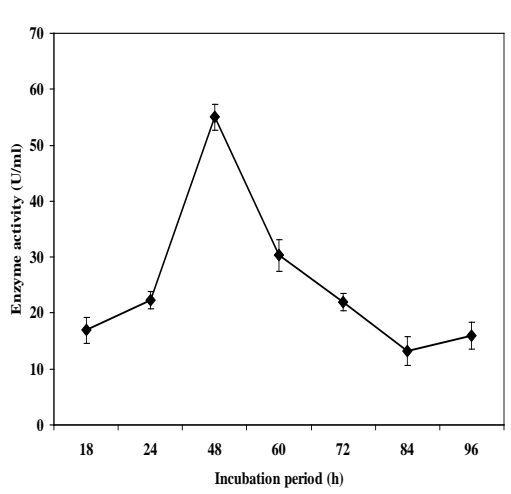

(A)Incubation period

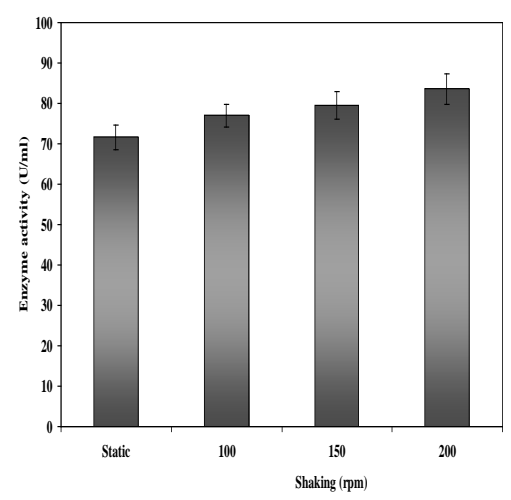

(D) Static and Shaking

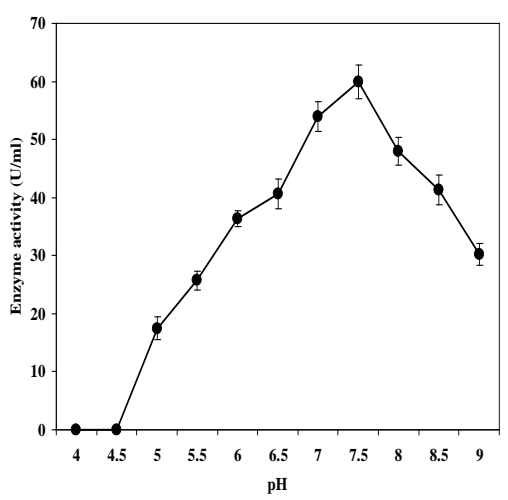

(B) $\mathrm{Ph}$

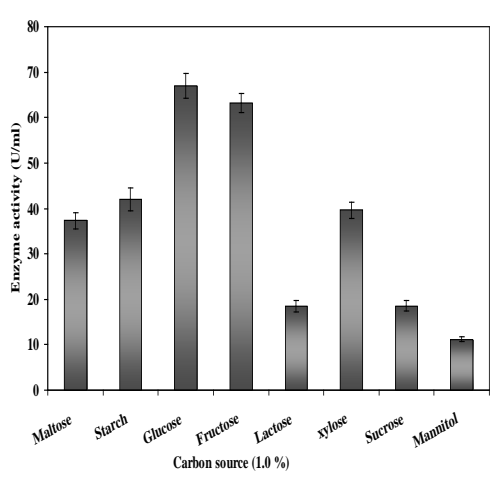

(E) Carbon source

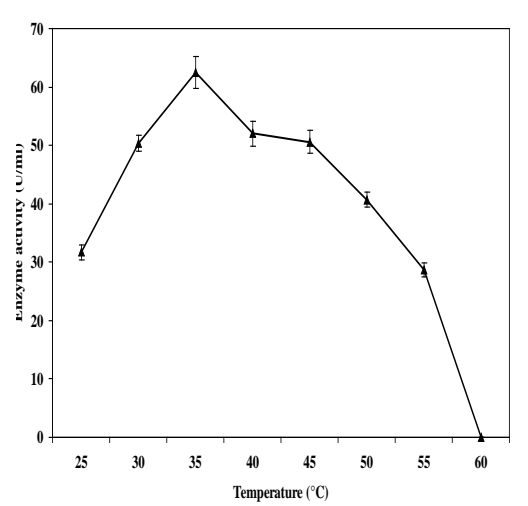

(C) Temperature

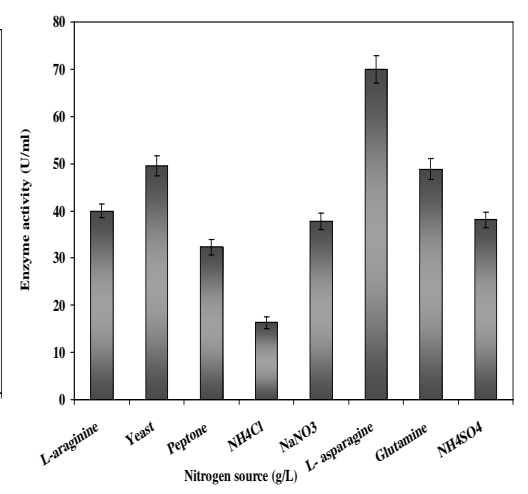

(F) Nitrogen source

Figure 4. Optimization of the production of $P$. aeruginosa L-asparaginase 


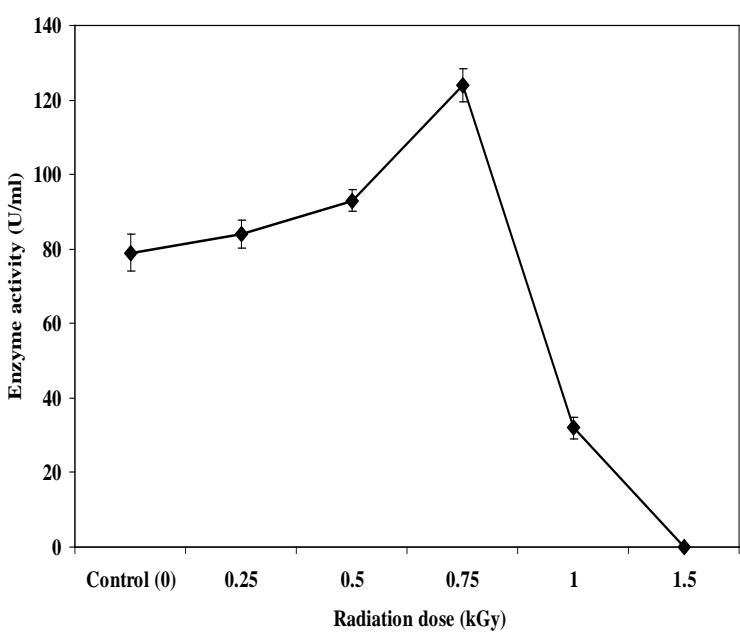

Figure 5. Effect of gamma radiation on $P$. aeruginosa Lasparaginase activity.

\subsection{Enzyme Purification}

L-asparaginase produced by $P$. aeruginosa in liquid media was purified by Ultra-filtration and combination of gel filtration and ion-exchange chromatography to obvious homogeneity with varying recovery and purification yield.

Results in Table 2 revealed that the final specific enzyme activity was $366 \mathrm{Um} / \mathrm{g}$ with 1.5 fold and 6.6\% yield. When El-Bessoumy et al. (2004) grown $P$. aeruginosa 50071 on solid-state fermentation, the purified enzyme final specific activity was $1900 \mathrm{IU} / \mathrm{mg}$, the purification rate was 106 -fold and the yield was $43 \%$.

L- asparaginase fractional purification by Sephadex G100 column chromatography. As a result of gel filtration chromatography on Sephadex, G-100 the specific activity increased to 1.5 fold with a $6.6 \%$ yield. Fractions with the highest activity were pooled and dialyzed at $4.0^{\circ} \mathrm{C}$ against distilled water (Figure 6).

Table 2. L-asparaginase purification profile.

\begin{tabular}{|c|c|c|c|c|c|c|c|c|}
\hline $\begin{array}{l}\text { Purification } \\
\text { Steps }\end{array}$ & $\begin{array}{l}\text { Volume } \\
\text { (ml) }\end{array}$ & $\begin{array}{l}\text { Enzyme activity } \\
(\mathrm{U} / \mathrm{ml})\end{array}$ & $\begin{array}{l}\text { Protein content } \\
(\mathrm{mg} / \mathrm{ml})\end{array}$ & $\begin{array}{l}\text { Total activity } \\
\text { (U) }\end{array}$ & $\begin{array}{l}\text { Total } \\
\text { protein } \\
\text { (mg) }\end{array}$ & $\begin{array}{l}\text { Specific } \\
\text { activity } \\
\text { U/mg }\end{array}$ & $\begin{array}{l}\text { Yield } \\
\%\end{array}$ & $\begin{array}{l}\text { Purification } \\
\text { fold }\end{array}$ \\
\hline $\begin{array}{l}\text { Culture filtrate (crude } \\
\text { extract) }\end{array}$ & 2730 & 124 & 0.48 & 338520 & 1310 & 245.8 & 100 & 1 \\
\hline $\begin{array}{l}\text { Precipitation by } \\
\text { amm.Sulphate (70\%) }\end{array}$ & 901 & 129 & 0.45 & 111711 & 405 & 287 & 33 & 1.17 \\
\hline Sephadex G100 & 160 & 139 & 0.38 & 22240 & 60.8 & 366 & 6.6 & 1.5 \\
\hline
\end{tabular}

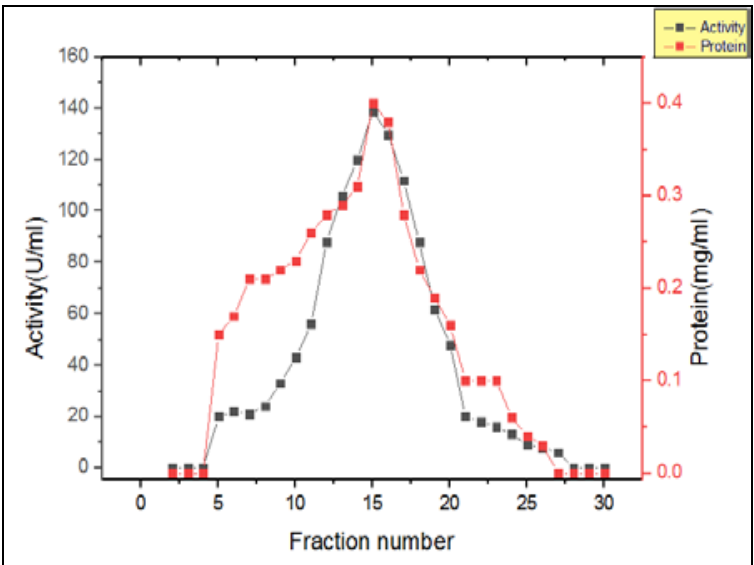

Figure 6. Fractional purification pattern of the L- asparaginase produced by $P$. aeruginosa applying Sephadex G-100 column chromatography.

In addition to demonstrating the purity of the enzyme, the molecular weight was measured. Pseudomonas aeruginosa L-asparaginase purified enzyme molecular weight was $123 \mathrm{KDa}$ (Figure 7).

The L-asparaginase sizes vary from one organism to another in terms of genus and species. The Pseudomonas L-asparaginase molecular size and subunits vary from a single subunit of 34-33 kDa under non-denaturing and denaturing conditions respectively (Shakambari et al., 2019). The molecular weight of Pseudomonas aeruginosa pure and crude enzyme samples are found to be 75KDa by Jois et al. (2013). Also, Pseudomonas aeruginosa Lasparaginase exists as a monomer with a size of $160 \mathrm{kDa}$ as reported by (El-Bessoumy et al., 2004). Thus, Lasparaginase shows a wide structural variation in the subunits of the above-mentioned bacteria.

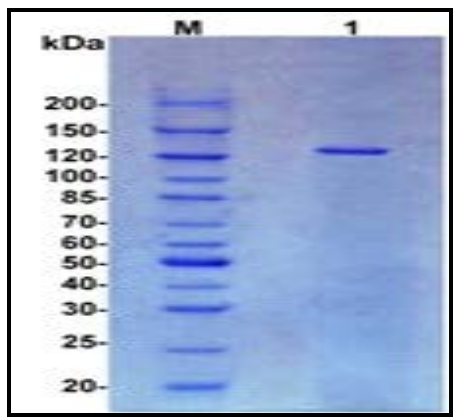

* Lane M =marker protein, Lane 1= purified enzyme.

Figure 7. SDS- PAGE of $P$. aeruginosa purified L-asparaginase.

\subsection{Properties of P. aeruginosa $L$ - asparaginase purified enzyme}

Clearly, after a 30 min incubation period, the maximum L-asparaginase enzyme activity was achieved (Figure 8A). This finding is consistent with (Komathi et al., 2013) who observed the maximum $P$. aeruginosa enzyme activity after $30 \mathrm{~min}$. The maximum recorded activity was also 30 min for Streptomyces noursei asparaginase enzyme (Kumar et al., 2011). The optimal $\mathrm{pH}$ value for $P$. aeruginosa purified L-asparaginase was $\mathrm{pH} 9$ (Figure 8B). El-Bessoumy et al. (2004) recorded comparable results for $P$. aeruginosa 50071. Moreover, Shukla and Mandal (2013) recorded maximum activity of Bacillus subtilis purified L-asparaginase at $\mathrm{pH}$ 9. For every enzyme, there is a specific optimal temperature beyond which there has been a decrease in activity (Kumar et al., 2011). In the current study, the optimum incubation temperature was reported at $35{ }^{\circ} \mathrm{C}$ (Figure 8C) for maximum activity of $P$. aeruginosa L-asparaginase. Also, the optimal temperature 
for the maximum activity of $P$. aeruginosa asparaginase enzyme was observed at $35^{\circ} \mathrm{C}$ by Komathi et al. (2013).

The findings in (Figure 8D) indicate that by increasing the L-asparagine concentration, the activity of Lasparaginase gradually increases. L-asparaginase maximum activity was determined at asparagine concentration of $200 \mathrm{mM}(167 \mathrm{U} / \mathrm{ml})$. P. aeruginosa SN004 L-asparaginase maximum production $(785 \mathrm{U} / \mathrm{ml})$ was achieved with $0.5 \%$ L-asparagine on an optimized medium as defined by Badoei-Dalfard (2015).

The activity of the enzyme decreased when of $\mathrm{Mg}^{2+}$,

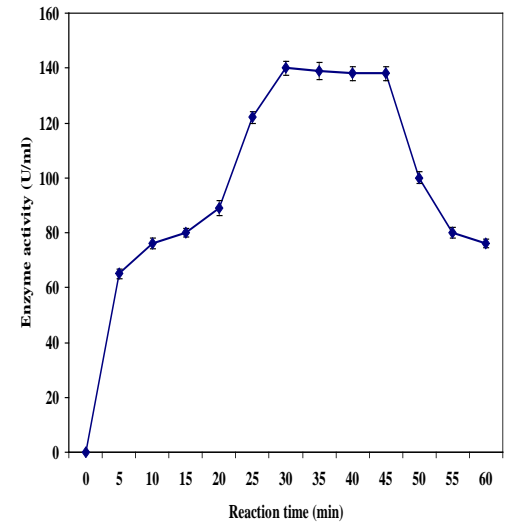

(A) Reaction time

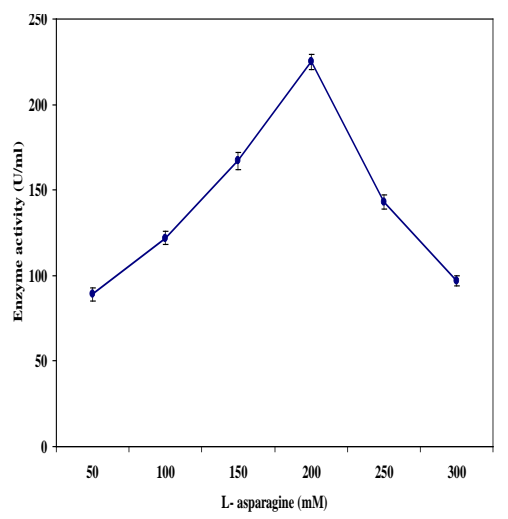

(D) substrate concentration

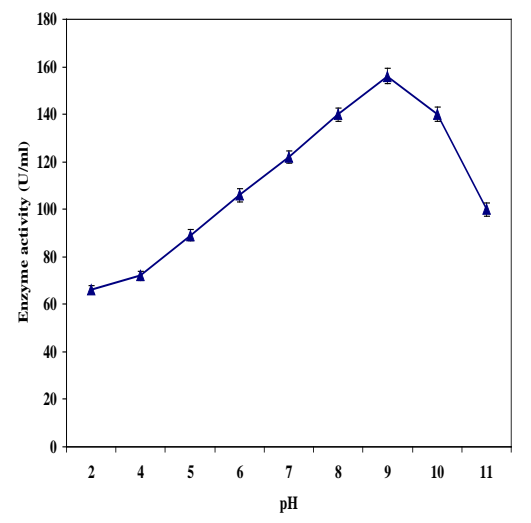

(B) $\mathrm{pH}$ level

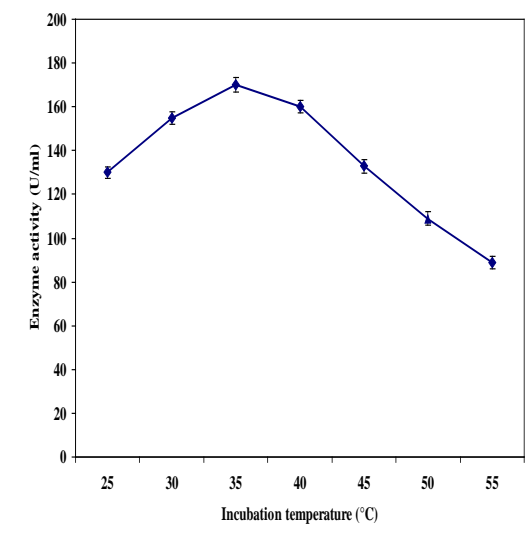

(C) Incubation temperature

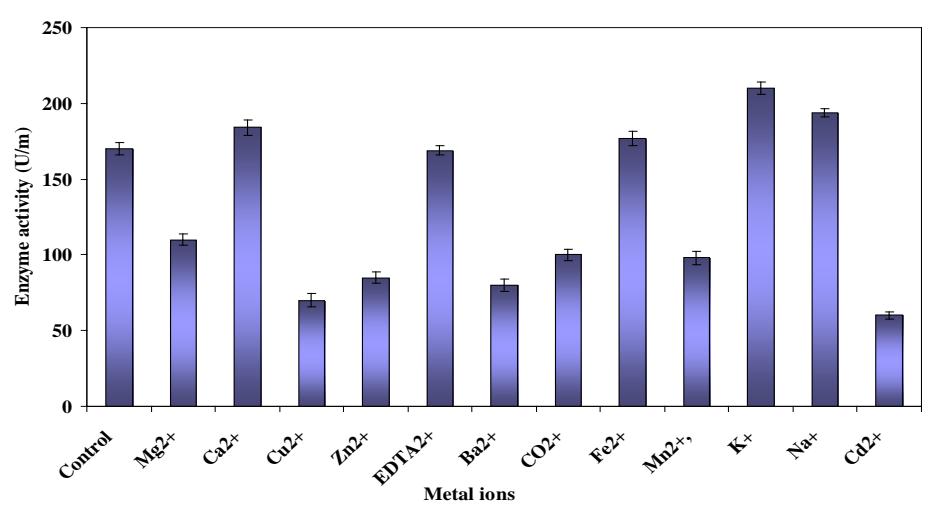

(E) Metal ions

Figure 8. Characteristics of $P$. aeruginosa L- asparaginase purified enzyme.

\subsection{Anticancer activity}

In the present study, three tumour cell lines were used to investigate the in vitro antitumor activity of $P$. aeruginosa L-asparaginase enzyme (Figure 9). Incubation of HEPG2-116 with progressive doses of the $P$. aeruginosa asparaginase enzyme causes progressive cell growth inhibition, as indicated by its $\mathrm{IC}_{50}$ value of 3.5 $\mu \mathrm{g} / \mathrm{ml}$. The enzyme anti-tumour activity against the breast adenocarcinoma MCF-7 was IC $_{50} 12.5 \mu \mathrm{g} / \mathrm{ml}$. The tested enzyme was found to have activity against HCT-116 cells $\left(\mathrm{IC}_{50}, 3.8 \mu \mathrm{g} / \mathrm{ml}\right.$ ) compared to the growth of the control (untreated cells). The in vitro cytotoxicity of Helicobacter pylori CCUG 17874 new L-asparaginase against a variety of cells has been studied by Cappelletti et al. (2008), they stated that gastric epithelial cells AGS and MKN 28 are most affected. When Moharam et al. (2010) examined the antioxidant and antitumor activities of Bacillus sp R36 asparaginase; they found two human cell lines were inhibited by the enzyme, including colon carcinoma (HCT116) and hepatocellular carcinoma (HEPG2-116) with IC $_{50}$ value of $218.7 \mu \mathrm{g} / \mathrm{ml}$ and $112.19 \mu \mathrm{g} / \mathrm{ml}$, respectively. 


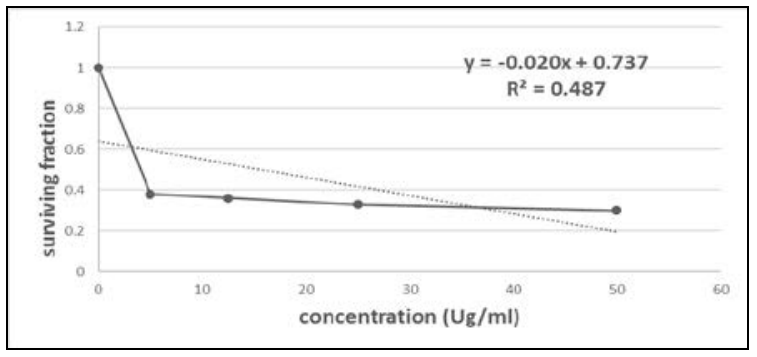

(A) HCT-116 IC $_{50}=3.8 \mu \mathrm{g} / \mathrm{ml}$

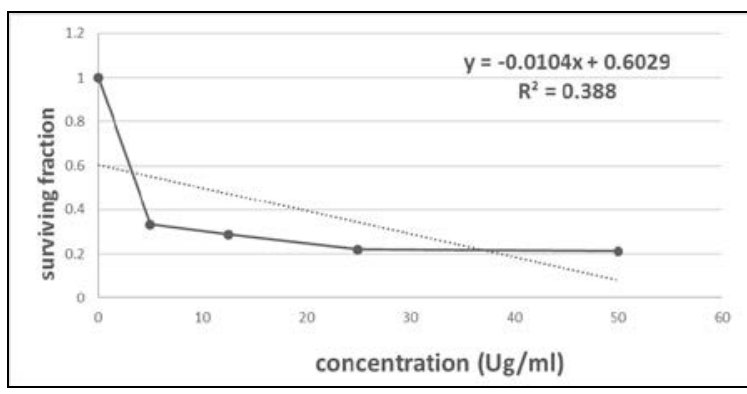

(B) HEPG2-116 IC50=3.5 $\mu \mathrm{g} / \mathrm{ml}$

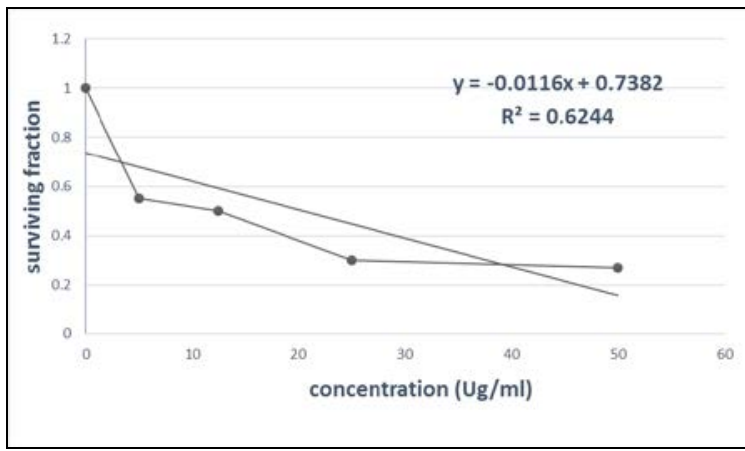

(C) MCF-7 IC ${ }_{50}=12.5 \mu \mathrm{g} / \mathrm{ml}$

The diagram represents the relation between the concentration (horizontal axis) and surviving fraction (vertical axis).

Figure 9. $P$. aeruginosa L-asparaginase toxic effect on cancer cells.

\section{Conclusion}

L-asparaginase is considered one of the therapeutic enzymes used in the treatment of blood cancer (ALL) in children. Using enzymes developed by these commercial strains causes adverse side effects for patients in the long run. So, finding new bacterial strains that can be used for L-asparaginase commercial production is essential. In this study, the most potent local bacterial isolate $P$. aeruginosa WCHPA075019 isolated from asparagus was selected for the production of L-asparaginase. The culture conditions, nutritional requirements, and low doses of gamma radiation were optimized to reach maximum lasparaginase productivity. The study was, moreover, extended to purify L- asparaginase and investigate its physicochemical properties. The purified enzyme preparation showed anti-cancer activity against 3 human cell lines. From the results, P. aeruginosa WCHPA075019 L-asparaginase may be evaluated clinically as an anticancer pharmaceutical agent for the tested cancer cell lines.
Declaration of competing interests:

None

\section{References}

Abd EI-Aziz A B and Hassan A A. 2010. Optimization of Microbial Elastase Production. Radiation Res appl Sci., 3 (4B): 1237-1257.

Abdelrazek N A, Elkhatib W F, Raafat M M and Aboulwafa M M. 2019. Experimental and bioinformatics study for production of L-asparaginase from Bacillus licheniformis: a promising enzyme for medical application. AMB Express., 9 (1): 39.

Alrumman S, Mostafa Y, Al-izran K, Alfaifi M, Taha T and Elbehairi S. 2019. Production and Anticancer Activity of an LAsparaginase from Bacillus licheniformis Isolated from the Red Sea, Saudi Arabia. Scientific Rep., 9(1):3756.

Arumugam T and Senthil K P. 2017. Optimization of media components for production of antimicrobial compound by Brevibacillus brevis EGS9 isolated from mangrove ecosystem. Microbiol Methods., 142: 83-89.

Atlas R M and Parks L C. 1993. Handbook of microbiological media. Boca Raton: CRC Press.

Awan M S, Tabbasam N, Ayub N, Babar M E, Rana S M and Rajoka M I. 2011. Gamma radiation induced mutagenesis in Aspergillus niger to enhance its microbial fermentation activity for industrial enzyme production. Molecular biology reports., 38(2): 1367-1374.

Badoei-Dalfard A. 2015. Purification and characterization of lasparaginase from Pseudomonas aeruginosa strain SN004: Production optimization by statistical methods. Biocatalysis and agricultural biotechnol., 4: 388-397.

Badoei-Dalfard A. 2016. L-asparaginase production in the pseudomonas pseudoalcaligenes strain JHS-71 isolated from Jooshan Hot-spring. Molecular biology Res communications., 5(1): 1-10.

Balouiri M, Sadiki M and Ibnsouda S. 2016. Methods for in vitro evaluating antimicrobial activity: A review. Pharm analy., 6(2): 71-79.

Bhargavi M and Jayamadhuri R. 2016. Isolation and Screening of Marine Bacteria Producing Anti-Cancer Enzyme L-Asparaginase. Am J Marine Sci., 4(1): 1-3.

Bollag D M, Rozyeki MD and Edelstein S J. 1996. Protein Methods $2^{\text {nd }}$ ed. Wiley Liss., New York. p. 110.

Brenner D J, Krieg N R, Staley J T and Garrity G M (Eds.). 2005. Bergey's Manual ${ }^{\circledR}$ of Systematic Bacteriology: Volume Two: The Proteobacteria, Part A Introductory Essays. Springer-Verlag US.

Cappelletti D, Chiarelli LR, Pasquetto MV, Stivala S, Valentini G and Scotti C. 2008. Helicobacter pyloril-asparaginase: a promising chemotherapeutic agent. Biochem Biophys Res Communications., 377(4): 1222-1226.

Chand S, Mahajan R, Prasad J, Sahoo D, Mihooliya K, Dhar M and Sharma G. 2020. A comprehensive review on microbial 1 -asparaginase: Bioprocessing, characterization, and industrial applications. Biotechnol Appl Biochem., 67(4): 619-647.

Egler R A, Ahuja S P and Matloub Y. 2016. L-asparaginase in the treatment of patients with acute lymphoblastic leukemia. Pharm and pharmacotherapeutics., 7(2): 62-71.

El-Bessoumy A, Sarhan M and Mansour J. 2004. Production, Isolation, and Purification of L-Asparaginase from Pseudomonas aeruginosa 50071 Using Solid-state Fermentation. BMB Reports., 37(4): 387-393.

Fatima N, Khan M M and Khan I A. 2019. L-asparaginase produced from soil isolates of Pseudomonas aeruginosa shows potent anti-cancer activity on HeLa cells. Saudi J Biol sci., 26(6): 1146-1153. 
Gulati R, Saxena R and Gupta R. 1997. A rapid plate assay for screening L-asparaginase producing micro-organisms. Lett Appl Microbiol., 24(1): 23-26.

Gutierrez J, Pan Y, Koroniak L, Hiratake J, Kilberg M and Richards N. 2006. An Inhibitor of Human Asparagine Synthetase Suppresses Proliferation of an L-Asparaginase-Resistant Leukemia Cell Line. Chem and Biol., 13(12): 1339-1347.

Horvath T D, Chan W K, Pontikos M A, Martin L A, Du D, Tan L, Konopleva M, Weinstein N J and Lorenzi L P. 2019. Assessment of l-asparaginase pharmacodynamics in mouse models of cancer. Metabolites., 9(1): 10.

Imada A, Igarasi S, Nakahama K and Isono M. 1973. Asparaginase and Glutaminase Activities of Micro-organisms. General Microbiol., 76(1): 85-99.

Jois S, Lakshmikantha RY and Rai P S. 2013. Study On Production, Purification And Characterisation Of L-Asparaginase From Escherichia Coli And Pseudomonas Aeruginosa. Int J Pharm, Chem Biol Sci., 3(3): 565-570

Kante R, Somavarapu S, Vemula S, Kethineni C, Mallu M and Ronda S. 2019. Production of Recombinant Human Asparaginase from Escherichia coli under Optimized Fermentation Conditions: Effect of Physicochemical Properties on Enzyme Activity. Biotechnol Bioprocess Eng., 24(5): 824-832.

Khan I, Jahan P, Hasan Q and rao P. 2019. Genetic confirmation of T2DM meta-analysis variants studied in gestational diabetes mellitus in an Indian population. Diabetes and metabolic syndrome., 13 (1): 688-694.

Komathi S, Rajalakshmi G, Savetha S and Balaji S. 2013. Isolation, production and partial purification of l-asparaginase from Pseudomonas aeruginosa by solid state fermentation. Scholars Academic J Pharm., 2(2):55-59.

Kumar S, Dasu V V and Pakshirajan K. 2011. Studies on pH and thermal stability of novel purified L-asparaginase from Pectobacterium carotojorum MTCC 1428. Mikrobiologiia., 80(3): 349-355.

Kuwabara T, Prihanto A, Wakayama M and Takagi K. 2015. Purification and Characterization of Pseudomonas aeruginosa PAO1 Asparaginase. Procedia Environ Sci., 28: 72-77.

Laemmli U K. 1970. Cleavage of Structural Proteins during the Assembly of the Head of Bacteriophage T4. Nature., 227: 680685.

Lalitha Devi AS and Ramanjaneyulu R. 2016. Isolation of LAsparaginase Producing Microbial Strains from Soil Samples of Telangana and Andhra Pradesh States, India. India. Int J Current Microbiol Appl Sci., 5(10): 1105-1113.

Lowery O H, Rosebrough N J, Farr A L and Randall R J. 1951. Protein measurement with the Folin phenol reagent. Biological Chem., 139: 265-275.

Magaldi S, Mata-Essayag S, Hartung de Capriles C, Perez C, Colella M, Olaizola C and Ontiveros Y. 2004. Well diffusion for antifungal susceptibility testing. Int $J$ infectious diseases., 8(1): 39-45.

Manna S, Sinha A, Sadhukhan R and Chakrabarty S.1995. Purification, characterization and antitumor activity of lasparaginase isolated from Pseudomonas stutzeri MB-405. Current Microbiol., 30(5): 291-298.

Moharam M E, Gamal-Eldeen A M and El-Sayed S T. 2010. Production, Immobilization and Anti-tumor Activity of LAsparaginase of Bacillus sp R36. Am Sci., 6(8):131-140.

Narta U, Roy S, Kanwar S and Azmi W. 2011. Improved production of l-asparaginase by Bacillus brevis cultivated in the presence of oxygen-vectors. Bioresource Technol., 102(2): 20832085.
Olukunle O F and Ajayi O E. 2018. Screening Wild and Mutant Strains of Asperqillus flavus and Asperqillus niqer Isolated from Plantain Stalks for Amylase Production. Jordan J Biol Sci., 11(5): 557 - 562.

Pallem C. 2019. Solid-state fermentation of corn husk for the synthesis of Asparaginase by Fusarium oxysporum. Asian $J$ Pharm Pharm., 5(4):678-681.

Paul D and Sinha S N. 2014. Extracellular Synthesis of Silver Nanoparticles Using Pseudomonas aeruginosa KUPSB12 and Its Antibacterial Activity. Jordan J Biol Sci., 7(4): 245 - 250.

Peterson R E and Ciegler A. 1969. L-Asparaginase production by Erwinia aroideae. Appl Microbiol., 17(6): 929-930.

Prakasham R, Hymavathi M, Ch Rao C, Arepalli S, Venkateswara Rao J, Kennady P K, Nasaruddin K, Vijayakumar J B and Sarma P N. 2010. Evaluation of Antineoplastic Activity of Extracellular Asparaginase Produced by Isolated Bacillus circulans. Appl Biochem Biotechnol., 160(1): 72-80.

Prakasham R, Rao C, Rao R, Lakshmi G and Sarma P. 2007. Lasparaginase production by isolated Staphylococcus sp.? 6A: design of experiment considering interaction effect for process parameter optimization. Appl Microbiol., 102(5): 1382-1391.

Qeshmi F I, Homaei A, Fernandes P and Javadpour S. 2018. Marine microbial L-asparaginase: Biochemistry, molecular approaches and applications in tumor therapy and in food industry. Microbiol Res., 208: 99-112.

Rajoka M I, Bashir A, Hussain S R S and Malik K A. 1998. $\gamma$-ray induced mutagenesis of Cellulomonas biazotea for improved production of cellulases. Folia Microbiol., 43: 15-22.

Reisz J, Bansal N, Qian J, Zhao W and Furdui C. 2014. Effects of Ionizing Radiation on Biological Molecules-Mechanisms of Damage and Emerging Methods of Detection. Antioxidants and Redox Signaling., 21(2): 260-292.

Saeed H, Soudan H, El-Sharkawy A, Farag A, Embaby A and Ataya F. 2018. Expression and Functional Characterization of Pseudomonas aeruginosa Recombinant 1. Asparaginase. Protein J., 37(5): 461-471.

Shakambari G, Ashokkumar B and Varalakshmi P. 2019. Lasparaginase - A promising biocatalyst for industrial and clinical applications. Biocatalysis and agricultural biotechnol., 17: 213224.

Shukla S and Mandal S K. 2013. Production optimization of extracellular L-asparaginase through solid- state fermentation by isolated Bacillus subtilis. Int Appl Biol Pharm Technol., 4 (1): 219-226.

Sinha R K, Singh H R and Jha S K. 2015. Production, purification and kinetic characterization of l-asparaginase from Pseudomonas fluorescens. Int J Pharm Pharm Sci., 7(1): 135-138.

Vichai V and Kirtikara K. 2006. Sulforhodamine B colorimetric assay for cytotoxicity screening. Nature protocols., 1(3): 11121116.

World Health Organization. 2015. The selection and use of essential medicines: report of the WHO expert committee, 2015 (including the 19th WHO model list of essential medicines and the $5^{\text {th }}$ WHO model list of essential medicines for children) (Vol. 994). World Health Organization.

Yamamoto S and Harayama S.1998. Phylogenetic relationships of Pseudomonas putida strains deduced from the nucleotide sequences of gyrB, rpoD and 16S rRNA genes. Int $J$ Systematic and Evolutionary Microbiol., 48(3): 813-819. 